Istanbul Finance Congress, November 1, 2019

\title{
TESTING THE PRODUCTIVITY BIAS HYPOTHESIS FOR BRAZIL
}

\section{DOI: 10.17261/Pressacademia.2019.1145 \\ PAP-IFC- V.10-2019(13)-p.68-71}

\section{Gulfer Vural}

Istanbul Medeniyet University, South Campus, Faculty of Political Science, Department of Economics, Istanbul, Turkey. gulfer.vural@medeniyet.edu.tr, ORCID: 0000-0002-7297-7545

\author{
To cite this document \\ Vural, G., (2019), Testing the productivity bias hypothesis for Brazil. PressAcademia Procedia (PAP), V.10, p.68-71. \\ Permemant link to this document: http://doi.org/10.17261/Pressacademia.2019.1145 \\ Copyright: Published by PressAcademia and limited licenced re-use rights only.
}

\section{ABSTRACT}

Purpose- Productivity Bias Hypothesis (Balassa-Samuelson hypothesis) implies that currency appreciates in a relatively more productive country. The focus of this study is to test productivity bias hypothesis for Brazil by employin time series data over the period $1980-2018$. Methodology- Time series data is analyzed by Autoregressive Distributed Lag (ARDL) method of cointegration.

Findings-Stationarity of the variables are supported by Augmented Dickey Fuller (ADF) and Phillips Perron (PP) tests. F bounds test and error correction model suggest that variables are cointegrated.

Conclusion- Empirical analysis does not support the evidence in favor of productivity bias hypothesis for Brazil over the selected period.

Keywords: Productivity bias hypothesis, Brazil.

JEL Codes: C22, F30

\section{INTRODUCTION}

Purchasing Power Parity (PPP) theory suggests that the exchange rate between currencies of two country is obtained as the ratio of the general price level. In the literature there are many study testing the validity of the theory but the results are not conclusive.Productivity differences across countries arise as one of the importantreasons about the deviations of exchange rates from the equilibrium level.

The independent studies of Balassa (1964) and Samuelson (1964) revealed Balassa-Samuelson hypothesis that is also known as Productivity Bias Hypothesis (PBH). According to the hypothesis, if a country is more productive than the other country then real exchange rate appreciates in the more productive country.

In this study Productivity Bias Hypothesis is tested for Brazil from 1980 to 2018 period.Although there are many studies testing PBH, there is no time series study that tests the validity of the hypothesis in Brazil. This study contributes to the literature in this sense.

The rest of the paper is organized as follows: Section 2 provides a brief literature review. Section 3 presents methodology and empirical analysis. Section 4 concludes.

\section{A BRIEF LITERATURE REVIEW}

The related literature is surveyed by Bahmani-Oskooee and Nasir (2005).

Cross Sectional Studies: Balassa (1964) tested the hypothesis as a first study. The study supports PBH. Other cross sectional studies: Kravis and Lipsey (1983), Clague (1986), Bergstrand(1991),Bergstrand (1992),Bahmani-Oskooee and Nasir (2001).

Time Series Studies: First time series study is conducted by Hsieh (1982) by using data for Germany and Japan for the 1954-1976 period. The findings support PBH.Other time series studies: Rogoff (1992), Egert (2002),Bahmani-Oskooee and Nasir (2004), Chowdhury (2012), Apergis (2013), Cardi and Restout (2015), Halıcıoglu and Ketenci (2018).

Panel Studies: By employing data of 14 OECD countries from 1970 to 1985 period Asea and Mendoza (1994)'s study was the first panel data study. Other panel data studies:De Gregorio et. al (1994), Canzonerietal.(1999, )Strauss (1999), Bahmani-Oskooee and Nasir (2001), Irandoust (2017)

\section{METHODOLOGY AND EMPIRICAL ANALYSIS}

Following Officer (1976), the relationship between real exchange rate and productivity differentials is expressed in Equation1.

$$
\mathrm{RER}_{\mathrm{t}}=\mathrm{a}_{0}+\mathrm{a}_{1} \mathrm{PROD}_{\mathrm{t}}+\varepsilon_{\mathrm{t}}
$$


RER $R_{t}$ is real exchange rate that is obtained by $\left(P_{i} / P_{u s}\right) E X . P_{i}$ is price level in country $i$ and $P_{u s}$ is price level in US and EX the exchange rate.PROD denotes productivity differential. $\mathrm{PROD}_{\mathrm{t}}=\left(\mathrm{PROD}_{\mathrm{i}} / \mathrm{PROD} \mathrm{D}_{\mathrm{us}}\right) \mathrm{PROD} \mathrm{D}_{\mathrm{i}}$ is productivity in country $\mathrm{i}$ and $\mathrm{PROD}$ us is productivity in $U S$. $\varepsilon_{\mathrm{t}}$ is the error term. Expected sign of slope parameter $\mathrm{a}_{1}$ is positive. Consumer price index is used for $\mathrm{P}_{\mathrm{i}}$. Productivity is measured by real GDP per capita. All data are taken World Bank, World Development Indicators Database.

In this study Pesaran et al. (2001) Autoregressive distributed lag model (ARDL) is used. Equation 2 below shows the ARDL representation of the model in Equation 1. ARDL method is invalid when the variables are I(2). When the variables are I(0) or I(1) or mixed the test is valid. In order to check that the variables are not I(2)Dickey and Fuller (1979),Augmented Dickey Fuller (ADF) and Phillips Perron (1988) (PP) tests are used. Table 1 shows the test results and existence of unit root is rejected by both tests for both variables.

$$
\Delta \mathrm{RER}_{\mathrm{t}, \mathrm{j}}=\alpha_{0}+\sum_{i=1}^{m 1} \alpha_{1 i} \Delta R E R_{\mathrm{t}-\mathrm{i}}+\sum_{i=0}^{m 2} \alpha_{2 i} \Delta P R O D_{\mathrm{t}-\mathrm{i}}+\alpha_{3} \mathrm{RER}_{\mathrm{t}-1}+\alpha_{4} \mathrm{PROD}_{\mathrm{t}-1}+\mathrm{v}_{\mathrm{t}}
$$

Table 1: Unit Root Test

\begin{tabular}{|l|l|l|}
\hline & ADF & PP \\
\hline rer & $-2.58^{* *}$ & $-3.74^{*}$ \\
\hline prod & $-2.64^{* * *}$ & $-2.68^{* * *}$ \\
\hline
\end{tabular}

Null hypothesis is the presence of the unit root. *, $* *, * * *$ denote rejection of the null hypothesis at the $1 \%, 5 \%$ and $10 \%$ significance levels respectively

The cointegration relationship between the variables are investigated by the bounds testing that is a Wald statistics ( $F$ statistics). The null hypothesis is no cointegration among the variables:

$\mathrm{H}_{0}: \alpha_{3}=\alpha_{4}=0$

$\mathrm{H}_{1}$ :at least one of $\alpha_{3}, \alpha_{4} \neq 0$

WhenF statistics is above the upper bound critical values then the null hypothesis is rejected. When the F statistics is below the lower bound critical value then the null hypothesis cannot be rejected. When the F statistics is between critical values then no conclusion can be drawn. Table 2 shows $\mathrm{F}$ bounds test results. The computed $\mathrm{F}$ statistics is above the upper bound critical value at $10 \%$ significance level.

\section{Table 2: Cointegration F Test}

\begin{tabular}{|l|l|l|l|l|l|l|}
\hline F-Statistics & 90\%LB & 90\%UB & 95\%LB & 95\%UB & 99\%LB & 99\%UB \\
\hline 4.15 & 3.02 & 3.51 & 3.62 & 4.16 & 4.94 & 5.58 \\
\hline
\end{tabular}

Error correction model (ECM) provides estimates of short run parametersafter determining the long run cointegration relationship between the variables. Equation 3 is the ECM representation of the model.

$$
\Delta \mathrm{RER}_{\mathrm{t}, \mathrm{j}}=\beta_{0}+\sum_{i=1}^{n 1} \beta_{1 i} \Delta R E R_{\mathrm{t}-\mathrm{i}}+\sum_{i=0}^{n 2} \beta_{2 i} \Delta P R O D_{\mathrm{t}-\mathrm{i}}+\lambda \mathrm{EC}_{\mathrm{t}-1+\mathrm{w}_{\mathrm{t}}}
$$

$E C_{t-1}$ is the error correction term and $\lambda$ is the speed of adjustment parameter. Negative and significant $E_{t-1}$ indicates cointegration among the variables as well.. Table 3 shows ECM estimation results and some regression diognastics. $\mathrm{EC}_{\mathrm{t}-1}$ is estimated as negative and statistically significant and therefore provides further evidence on the cointegration.

Table 3: Error Correction Model

\begin{tabular}{|l|l|l|l|l|l|l|l|}
\hline EC $_{\mathbf{T}-1}$ & t-stat & $\mathbf{R}^{\mathbf{2}}$ & DW Stat. & RSS & Normality & $\begin{array}{l}\text { Serial } \\
\text { Correlation }\end{array}$ & \begin{tabular}{l} 
Heteroscedasticity \\
\hline-0.06
\end{tabular} \\
\hline
\end{tabular}

Table 4 presents ARDL long run results. The slope parameter is estimated as negative and significant. Therefore for the selected period of time in Brazil, no evidence is found to support Productivity Bias Hypothesis. Finally, cumulative sum of recursive residuals and (CUSUM) and cumulative sum of squares of recursive residuals CUSUM ${ }^{2}$ tests of Brown et al. (1975) are used. Due to space constraints plots are not included. CUSUM and CUSUM² plots suggest stability of the model ( $S$ stands for stability).

Table 4: ARDL Long Run Results

\begin{tabular}{|l|l|l|l|l|}
\hline Model & $\begin{array}{l}\text { Coefficient Estimate of } \\
\text { Slope Parameter }\end{array}$ & t-stat & CUSUM & CUSUM $^{2}$ \\
\hline ARDL $(4,4)$ & -88.36 & $-2.06 * *$ & S & S \\
\hline
\end{tabular}

\section{CONCLUSION}

The purpose of this study is to determine whether Productivity Bias Hypothesis is supported in Brazil over the 1980-2018 period. Autoregressive distributed lag model (ARDL) is used. Firstly, Augmented Dickey Fuller (ADF) and Phillips Perron (PP) tests are used to check that none of the variables is I(2). Since ARDL is invalid when one of the variables is I(2). F bounds test suggests cointegration among the 
variables. Then Error Correction Model is estimated. Lastly ARDL long run results imply that the slope coefficent is negative and significant. Therefore for the considered period of time no support for PBH is obtained in Brazil.

\section{REFERENCES}

Asea, P. K., Mendoza, E. G. (1994). Balassa-Samuelson model: An overview. Review of International Economics, vol. 2, no. 3,p. $191-200$.

Apergis, N. (2013), The domestic Balassa-Samuelson effect of inflation for the Greek economy. Applied Economics, vol. 45, no. 23, p. 32883294.

Bahmani-Oskooee, M.O., Nasir, A. B. M. (2001). Panel data and productivity bias hypothesis. Economic Development and Cultural Change,vol. 49 , p. 393-402.

Bahmani-Oskooee, M., Nasir, A.B.M. (2005), Productivity bias hypothesis andthe purchasing power parity: A review article. Journal of Economic Surveys, vol.19, no.4, p. 671-696.

Balassa, B. (1964). The Purchasing-Power-Parity Doctrine: AReappraisal. Journal of Political Economy,vol. 72, no. 6, $584-596$.

Bahmani-Oskooee, M. , Nasir, A.B.M. (2004), ARDL approach to test the productivity bias hypothesis. Review of Development Economics, vol. 8 , no. 3, p. 483-488.

Bergstrand, J. H. (1991). Structural determinants of real exchange rates and national price levels: Some empirical evidence. American Economic Review, vol. 81, p. 325-334.

Bergstrand, J.H.(1992).Realexchange rates, national pricelevels, and the peach dividend. American Economic Review, vol. 82, p. 56-61.

Brown, R.L., Durbin, J., Evans, J.M. (1975), Techniques for testing the constancy of regression relations over time. Journal of the Royal Statistical Society, vol. 37, no. 1, p. 149-163.

Canzoneri, M. B., Cumby, R. E. , Diba, B. (1999). Relative labour productivity and the real exchange rate in the long run: evidence for a panel of OECD countries.Journal of International Economics vol. 47, p. 245-266.

Cardi, O., Restour, R. (2015), Imperfect mobility of labor across sectors: a reappraisal of the Balassa-Samuelson effect. Journal of International Economics, vol. 97 , no. 2, p. 249-265.

Chowdhury, K. (2012), The real exchange rate and the Balassa-Samuelson hypothesis in SAARC countries: an appraisal. Journal of the Asia Pacific Economy, vol. 17, no. 1, p. 52-73.

Clague, C. K. (1986), Determinants of national price level: Some empirical results. The Review of Economics and Statistics vol.68, no. 2, p. 320323.

De Gregorio, J., Giovannini, A., Wolf, H. C. (1994). International evidence on tradables and nontradables inflation. European Economic Review, vol. 38, p. 1225-1244.

Dickey, D. A., Fuller, W. A. (1979). Distribution of the estimators for autoregressive time series with a unit root. Journal of the American Statistical Association, vol. 74, no. 366a, p. 427-431.

Egert, B. (2002), Does the productivity-bias hypothesis hold in the transition countries: evidence from five CEE economies in the 1990s. Eastern European Economies, vol. 40, no. 2, p. 5-37.

Halıcıoglu, F., Ketenci N. (2018). Testing the Productivity Bias Hypothesis in Middle East Countries. Journal of Economic Studies, vol. 45, no.5, p.922-931.

Hsieh, D.A. (1982), The determination of the real exchange rate: the productivityapproach.Journal of International Economics, vol.12, p.355362.

Irandoust, M. (2017), Symmetry, proportionality and productivity bias hypothesis: evidence from panel-VAR models. Economic Change and Restructuring, vol. 50, no. 1, p. 79-93.

Kravis, I. B., Lipsey, R. E. (1983). Toward and explanation of National price levels. Princeton Studies in International Finance. Princeton, NJ: Princeton University, International Finance Section.

Officer, L. H. (1976). The productivity bias in purchasing power parity: An econometric investigation. International Monetary Fund Staff Papers vol.23, p. 545-579.

Pesaran, H.M., Shin, Y. , Smith, J.R. (2001), Bounds testing approaches to the analysis of relationships. Journal of Applied Econometrics, vol. 16 , no. 3, p. 289-326.

Phillips, P. C., Perron, P. (1988). Testing for a unit root in time series regression. Biometrika, vol. 75, no. 2, p.335-346. https://doi.org/10.1093/biomet/75.2.335 
Samuelson, P. (1964). Theoretical Notes on Trade Problems. Review of Economics and Statistics, vol.46, p. 145-154.

Strauss, J. (1999). Productivity differentials, the relative price of non - tradables and real exchange rates. Journal of International Money and Finance, vol. 18, p. 383-409.

Rogoff, K. (1992),Traded goods consumption smoothing and the random walk behavior of the real exchange rates. Bank of Japan Monetary and Economic Studies, vol. 10, no. 2, p. 1-29. 